ENTREPRENEURSHIP AND SUSTAINABILITY ISSUES

ISSN 2345-0282 (online) http://jssidoi.org/jesi/ 2021 Volume 9 Number 1 (September) http://doi.org/10.9770/jesi.2021.9.1(7)

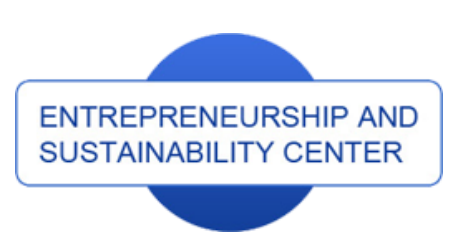

Publisher

$\underline{\text { http://jssidoi.org/esc/home }}$

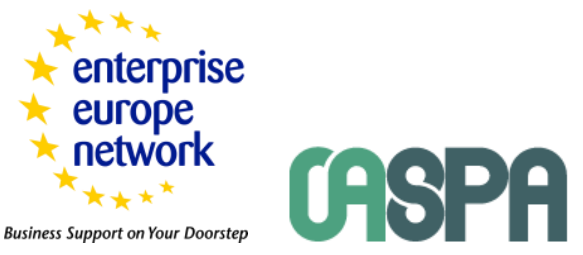

1) Clarivate

Analytics

\title{
AUDITING AS AN EFFECTIVE MEAN OF COMMUNICATION ON ENVIRONMENTAL, SOCIAL AND GOVERNANCE ISSUES IN BRAZIL
}

\author{
Washington Lopes da Silva ${ }^{1}$, Joshua Onome Imoniana ${ }^{2}$ \\ ${ }^{1,2}$ School of Economics, Management \& Accounting - University of Sao Paulo, \\ Prof. Luciano Gualberto Ave 908, 05508-010 Sao Paulo, Brazil \\ E-mails: ${ }^{1}$ washington.lopes2@usp.br; ${ }^{2}$ josh.imoniana@usp.br
}

Received 15 March 2021; accepted 26 May 2021; published 30 September 2021

\begin{abstract}
The study investigates the understanding of the relationships between the adoption of the sustainability standards by the organisations, audit role and the effective communication based on Environmental, Social and Governance (ESG). The ESG has evolved over time in several countries and has attracted some concerns on the part of stakeholders. Thus, our research responds to the question of what the understanding of the relationship between audit communication and ESG risks is. Data was constructed from the Symposium organized by the Brazilian Central Bank addressing the future of sustainability and from interview of experts. We used the discourse analysis to work on the data corpus. Our results reveal that to comprehend the relationship between auditing and communication on ESG issue, understanding risk analysis and the matrices, planning and rules of effective communication turns sine qua non. De facto, a well written report and communicated in a timely manner instils confidence in the auditee by procuring response and giving remedies to weaknesses without fear or favour. Results also indicate that auditing will have a key role to play through their methodologies noting that they are competent to carry out the work. Overall, our study contributes to research on ESG, auditing communication and stakeholders' relationships.
\end{abstract}

Keywords: ESG; sustainability; audit, effective communication; auditing; stakeholders; SDG; Brazil

Reference to this paper should be made as follows: Lopes da Silva, W., Onome Imoniana, J. 2021. Auditing as an effective mean of communication on environmental, social and governance issues in Brazil. Entrepreneurship and Sustainability Issues, 9(1), $103-122$. http://doi.org/10.9770/jesi.2021.9.1(7)

JEL Classifications: $\mathrm{O} 30, \mathrm{O} 44$ 


\section{ENTREPRENEURSHIP AND SUSTAINABILITY ISSUES}

ISSN 2345-0282 (online) http://jssidoi.org/jesi/

2021 Volume 9 Number 1 (September)

http://doi.org/10.9770/jesi.2021.9.1(7)

\section{Introduction}

The United Nations (UN) has 17 Sustainable Development Goals (SDGs) (Leal Filho, 2018). This said goal worked on by the UN would meet the most urgent environmental, political and economic challenges of our time. In view of the aforementioned, the coverage of our study is objective 16 - peace, justice and effective institutions. De facto, companies and organizations in general ought to be sustainable, in order to meet their social goal.

In the same vein, the world of financial investments can have significant changes, which consider sustainability criteria, or ESG - Environmental, Social and Governance (World Economic Forum, 2020). These criteria assume that companies need to demonstrate that more and more they are sustainably generating indicators and monitoring the performance of their actions so as not to compromise their new scenario of ESG.

In this said scenario, auditing will play a key role in this new sustainability and ESG context in the companies. In fact, auditing will have to improve their communication role in order to enhance their support of corporate governance.

Prior researchers, such as Nizam et al (2019), Batae et al (2020), Giudice and Rigamonti (2020), SASB (2021), Hargie et al (2002), Goldhaber (1977), Imoniana et al (2021) and United Nations Programme (2021), Qureshi et al (2019) and Garcia et al (2017) have ventured to address social and environmental sustainability, ESG, quality scores of ESG, sustainability accounting, auditing communication, sustainability technology and the financial market, respectively. However, no study has addressed ESG and auditing communication enblock so, this study therefore resolves to fill this research gap. In line with aforementioned, our research responds to the question: what is the understanding of the relationship between audit communication and ESG risks?

This study is arranged in the following order: the next section describes the background literature in the existing databases. Section 3 provides a description of the research methodology and data construction. Section 4 analyses the data and results, while section 5 paves the way for discussion, capitalizes on the reflexivity on the results and focusing on the main stakeholders. Section 6 gives the conclusion of the article.

\section{Background}

\subsection{The ESG in the Corporate Environment}

Today's corporate environment is undergoing significant changes owing to globally adopted standards to tackle the problem of sustainability; such as the 2015 Paris Agreement, which made it mandatory to decarbonize participating countries (Paris, 2021); China's national carbon trading system in 2017 (China, 2021); by 2030 India aims to make a country with a high proportion of renewable energy (India, 2021). Similarly, the Central Bank of Brazil launched a sustainability agenda in September 2020, with the objective of standardizing and monitoring the national financial system in sustainability aspects (BC\#Sustentabilidade, 2020).

The achievement of the expected goals become more demanding, when inserted in the context of the ESG, which defined criteria to be followed. Nizam et al (2019) mentioned that establishing ESG policies is a process that incurs costs for setting the ESG framework, due diligence, and current disclosure policies.

However, as there is not just a symbology of how to measure ESG performance, an important role to be played is to crave an indulgence for the explanation of practices and results of companies that have ESG. In September 2020, the World Economic Forum in conjunction with the Big 4 (Deloitte, EY, KPMG and PwC) released a document entitled Measuring Stakeholder Capitalism Towards Common Metrics and Consistent Reporting of Sustainable Value Creation. This document brought to limelight the initiative for companies in general to seek a measurable and comparative form of the ESG criteria applied to their businesses. World Economic Forum (2020) defines a core set of "Stakeholder Capitalism Metrics" (SCM) and disclosures that can be used by IBC (International Business Council) members to align their mainstream reporting on performance with environmental, ESG indicators and track their contributions towards the SDGs (Sustainable Development Goals) on a consistent manner. 


\section{ENTREPRENEURSHIP AND SUSTAINABILITY ISSUES}

ISSN 2345-0282 (online) http://jssidoi.org/jesi/

2021 Volume 9 Number 1 (September)

http://doi.org/10.9770/jesi.2021.9.1(7)

Another aspect to be considered today in the ESG criteria is the impact that the COVID-19 will play on the sustainability indicators of companies. According to Batae et al (2020) the ESG criteria and financial performance are expected to change significantly due to the pandemic.

As there is no universal standardization of ESG factors that apply to all companies the process of analysing the ESG criteria becomes even more complex. Chatterji et al (2016) and Delmas and Blass (2010) observed that there is evidence that ESG ratings tend to be different among the rating agencies. Thus, there is still a way to go to obtain measurable and comparable standards of the ESG criteria, considering their materiality, as well as centralizing on regulatory body for supervision.

Materiality principles definition (2021) states that an accounting standard can be ignored if the net impact of doing so has such a small impact on the financial statements that a reader of the financial statements would not be misled. This is true, inasmuch as no harm has been caused by material misstatement through the disclosure.

The investors' need for their assessment and scrutiny have created demand for specialized rating services (Giudice and Rigamonti, 2020); so also, will the use of indicators be imperative. For investors, the lack of a single reporting standard for companies can be a barrier when deciding where to invest. Following (Vodovoz et al (2020), the plethora of environmental, social, and institutional investors, asset managers, lenders, credit ratters, and insurers are increasingly relying on companies' ESG disclosures to make important decisions.

In any case, it is possible to highlight several regulatory instruments that will give clearance in the definition of the metrics of the ESG criteria, such as, The Ten Principles of the UN Global Compact (2021); Sustainability Accounting Standards Board (SASB, 2021); Global Reporting Initiative (Szczepankiewicz, 2021); International Integrated Reporting Council (IIRC, 2021); International Standards Organization (ISO 26000, 2021); Australian Stock Exchange, Listing Rule 4.10.17 (ASE, 2021); China State-Owned Assets Supervision and Administration Commission, Directive (CSASAC, 2021); Climate Disclosure Standards Board, The CDSB Reporting Framework (CDSB, 2021)]; France, Eccles et al (2011); Germany, Eccles et al (2011); Johannesburg Stock Exchange, Listing requirements (2021)]; Singapore Stock Exchange, Policy Statement on Sustainability Reporting (2021); Brazil, ESG Products and Services - Stock Exchange (B3, 2021) etc.

However, regardless of the form and communication channels used to report the ESG criteria, the important thing is to ensure the existence, integrity and objectivity of the information offered and allow it to be easily communicated to the stakeholders. Thus, drawing on Giudice and Rigamonti (2020), our inference may be different particularly when we take a second look at audited and yet to be audited financial statements.

Finally, the primary instrument to ensure the veracity of such information is for the company to use a good audit communication process, whether internal or external, while reporting to stakeholders. In line with this, evaluations by ESG rating agencies are made using complex questionnaires and analysis of public information sources (Escrig-Olmedo et al 2010).

\subsection{The Communication of Audit Engagements and ESG issues}

According to Hargie et al (2002), effective communication is central to business success, as such, it should be an integral part of strategic planning for all organizations. Where an organizational communication lacks effectiveness the results tend to be bad. What is currently the solution to avoid errors in audit communication is the professional standardization of reports, which is described in the International Standard for Professional Practice of Internal Audit. 2400 - Communicating Results (The IIA, 2017).

What is often found in the current literature is the discourse of the communication of audit papers that revolves around the writing of the report, and this is a matter of discussion (Chambers, 2017). Thus, making one to infer that a good report writing results in a call to action, while the opposite would lead to inappropriate actions or inaction. In other words, a well written report and communicated in a timely manner instils confidence in the auditee by procuring response, accordingly and giving remedies to weaknesses pinpointed without fear or favour. According to Bobek (2012), there is practice-oriented evidence on the importance of auditor interaction and auditee in successfully addressing and solving job challenges. 


\section{ENTREPRENEURSHIP AND SUSTAINABILITY ISSUES}

ISSN 2345-0282 (online) http://jssidoi.org/jesi/ 2021 Volume 9 Number 1 (September) http://doi.org/10.9770/jesi.2021.9.1(7)

According to Golen et al (1997) for example, if an auditee is pragmatic and the auditor presents information that is theoretical and extremely complex, the auditee could become uncomfortable and be perceived as uncooperative. In this case, restructuring the message to be more practical can be the first step in removing a communication barrier. Similarly, Archambeaut and Morgen (2010)], to minimize interpersonal problems, the auditor must build an environment conducive to communication flowing objectively and without conflicts, such as using euphemisms in his verbal communications, pay attention to the body language of the participants, in order to perceive the reactions of the auditee and be able to minimize the language during a discussion. Sure, minimising communication error lag restores the auditor integrity. Thus, following Scott et al (1999) for an audit to be successful, it depends on the commitment of senior management, because without their support it becomes exhaustive to perform the audit. In addition, according to same authors, without the support of senior management, it is often difficult to convince other officials that the results of the audit will be taken seriously.

Thus, the audit report must fulfil its role in transmitting relevant messages to this public, correlating the weaknesses found with the sociological and political strategy Bobek (2012), in order to direct efforts toward the goals established by senior management. In addition, to Marks (2017), it is then perceived that one of the problems in the communication of audit work is directly related to the writing of the report, as an example: intensifying the problem encountered, using words that generate conflicts of understanding between the parties.

De facto, the communication of audit engagements begins before the fieldwork, determining the focus of what to achieve. Concerning this Shelby et al (1996) observed that the determination of the focus and scope of the audit considers what the audit client intends from the audit engagement, and also take into consideration the knowledge and skills that the audit team has, and what is possible within the allotted time.

According to Cohen et al (2007) all companies, regardless of size, should strive to maintain strong internal controls and provide a control environment that supports solid reporting.

However, for communication to stakeholders be effective, auditing and governance bodies must maintain a synergy of what is expected as an audit communication method aligned with the organization's business. According to Golhaber (1977), the results of the audit may be reported orally and in writing to the appropriate public. A summary of the report may contain conclusions and recommendations, being prepared to disseminate information in the company. Another report containing executive information can be forwarded to the audit committee, for example.

In any case, the auditors, with the necessary training on ESG issues, being strategically aligned with the company's business, following the best practices for risk analysis, preparation of audit planning, execution of the job, will be able to communicate effectively with stakeholders. Following Fornelli (2016), improvements in audit quality go hand in hand with efforts to improve audit communication and transparency. Finally, in so far as we draw upon the literatures our argument further expands on the understanding of the relationship between audit communication and ESG risks which can be minimised through collaborative auditing engagement. According to Roy (2013), collaborative auditing will increase value for the business, while reducing gaps and real risks.

\section{Methodology and Data Construction}

The methodology adopted is interpretative, based on a constructivist perspective, according to King (2004). Knowledge was constructed based on understanding, through social constructivism that emphasizes the importance of culture and context in focus (Imoniana et al 2021).

A qualitative approach was used to construct discourse analysis, based on the Discourse Theory (DT), which the discursivity of social interaction explains the political aspects and their respective agendas of the various actors involved (Laclau and Mouffe, 2001).

According to Derry (1999) the greatest importance of discourse lies in the construction of social life. A qualitative study was elaborated with data collected from publicly available sources, with the objective of analysing the focus of the research (Gill, 2000). 
Firstly, we draw from the debate sponsored by the Brazilian Central bank, involving several participants of the financial market around the world, in which the BC\# Sustainability agenda was lunched. The aim of this debate, which lasted about two hours, was to highlight the importance of ESG and discuss the responses to the new challenge of the Central Bank of Brazil in the face of sustainability (Castka et al, 2020). This debate was attended by distinguished guests from the global financial sector, such as, Mark Carney, United Nations Special Envoy for Climate Action and Finance; Larry Fink, CEO of Blackrock; Carola Schuler, Managing Director of Banks for Europe, Middle East and Africa at Moody's; Marcio Lopes, president of the Organization of Brazilian Cooperatives (OCB); Isaac Sidney, president of the Brazilian Federation of Banks (Febraban); and Justine LeighBell, Deputy CEO of the Climate Bonds Initiative (CBI).

The agenda of The Central Bank of Brazil, according to BC\# Sustentabilidade (2021), is comprised of strategic and dynamic agenda for socioenvironmental (S\&E) sustainability; promoting sustainable finance; Proper management of S\&E and climate risks within the National Financial System (SFN); incorporation of sustainability variables in the Central Bank of Brazil (BCB) decision-making process. As a main focus, the agenda addresses socio-environmental responsibility initiatives; partnerships; policies; supervision and regulation.

Finally, we interviewed 10 experts in the field, in order to triangulate our constructed data. The interviewees were treated with their initials, because the interviews were kept confidential. Due to the home-office situation generated by COVID19, the interviewees were invited and, after permission for individual scheduling with date and time the interviews were conducted virtually through remote online meeting applications. Each interview lasted around 50 minutes and the interviewees authorized the recording of their answers for later transcription. The demographic characteristics of the respondents can be observed in Table 1 .

Table 1. Profiles of the respondents.

\begin{tabular}{|c|c|c|c|c|}
\hline Respondent & Gender & Age & Experience & Profile \\
\hline (CAR) & $\mathrm{F}$ & 32 & 14 & $\begin{array}{l}\text { Specialist in accounting process auditing and ESG. Career developed in } \\
\text { the Big } 4 \text { and in the service sector. }\end{array}$ \\
\hline (FFS) & M & 40 & 17 & $\begin{array}{l}\text { Business Process and Support Audit Manager. Career developed in the } \\
\text { Big } 4 \text { and financial services sector. }\end{array}$ \\
\hline (FET) & M & 42 & 18 & $\begin{array}{l}\text { Senior Manager for Latin America responsible for business, } \\
\text { operational and ESG auditing processes. Career developed in the Big } 4 \\
\text { and in the banking and finance sector. }\end{array}$ \\
\hline (JED) & M & 62 & 35 & $\begin{array}{l}\text { CAE - Chief Audit Executive. Career developed in banking and } \\
\text { finance. }\end{array}$ \\
\hline (JES) & M & 38 & 16 & $\begin{array}{l}\text { Coordinating Auditor. Career developed in the Big } 4 \text { and in the } \\
\text { banking and finance sector. }\end{array}$ \\
\hline (MAG) & M & 36 & 12 & $\begin{array}{l}\text { Information Technology Audit Manager. Career developed in the Big } 4 \\
\text { and financial services sector. }\end{array}$ \\
\hline (PCM) & M & 56 & 32 & $\begin{array}{l}\text { Specialist in Information Technology auditing and Information } \\
\text { Security. Career developed in the Big } 4 \text { and in the banking and finance } \\
\text { sector. }\end{array}$ \\
\hline (ROR) & $\mathrm{F}$ & 47 & 22 & $\begin{array}{l}\text { Risk and Compliance Manager. for Latin America. Career developed in } \\
\text { the Big } 4 \text { and in the banking and finance sector. }\end{array}$ \\
\hline (RNA) & M & 37 & 17 & $\begin{array}{l}\text { Operational Process Audit Manager. Career developed in the Big } 4 \text { and } \\
\text { financial services sector. }\end{array}$ \\
\hline (TIY) & M & 64 & 38 & $\begin{array}{l}\text { CAE - Chief Audit Executive. Career developed in the banking and } \\
\text { finance sector. }\end{array}$ \\
\hline
\end{tabular}




\section{Analysis}

The analyses of this study considered the use of discourse analysis, supported by discourse theory for sociological, economic and political research, with the objective of providing an understanding of the relations between effective audit communication and ESG risks. This follows Imoniana and Imoniana (2020) who adopted discourse analysis, highlighting sociological, psychological and political interpretations to critique the data constructed in their study.

NVivo software was used to support the qualitative analyses of the interviews. Table 2 shows the words most cited in the interviews.

Table 2. Most cited words from interview comments.

\begin{tabular}{|c|c|c|c|}
\hline Word & Length & Count & Weighted Percentage \\
\hline audit & 5 & 154 & $2.85 \%$ \\
\hline think & 5 & 97 & $1.79 \%$ \\
\hline esg & 3 & 94 & $1.74 \%$ \\
\hline risk & 4 & 63 & $1.16 \%$ \\
\hline communication & 13 & 57 & $1.05 \%$ \\
\hline issues & 6 & 45 & $0.83 \%$ \\
\hline right & 5 & 43 & $0.79 \%$ \\
\hline know & 4 & 36 & $0.67 \%$ \\
\hline environmental & 13 & 32 & $0.59 \%$ \\
\hline work & 4 & 30 & $0.55 \%$ \\
\hline important & 9 & 29 & $0.54 \%$ \\
\hline committee & 9 & 28 & $0.52 \%$ \\
\hline companies & 9 & 28 & $0.52 \%$ \\
\hline effective & 9 & 26 & $0.48 \%$ \\
\hline issue & 5 & 26 & $0.48 \%$ \\
\hline management & 10 & 24 & $0.44 \%$ \\
\hline auditing & 8 & 23 & $0.43 \%$ \\
\hline auditor & 7 & 23 & $0.43 \%$ \\
\hline related & 7 & 23 & $0.43 \%$ \\
\hline bank & 4 & 22 & $0.41 \%$ \\
\hline internal & 8 & 22 & $0.41 \%$ \\
\hline board & 5 & 20 & $0.37 \%$ \\
\hline external & 8 & 20 & $0.37 \%$ \\
\hline information & 11 & 19 & $0.35 \%$ \\
\hline knowledge & 9 & 19 & $0.35 \%$ \\
\hline report & 6 & 19 & $0.35 \%$ \\
\hline
\end{tabular}

According to Table 2, key words highlighted with more than $1 \%$ frequency in interviews were audit, with $2.85 \%$, ESG with $1.79 \%$ and risk with $1.16 \%$, communication with $1.05 \%$. As the words says it all, this confirms our understanding of the relationship between audit communication and ESG risks. In addition, we also observed in the Word Cloud Figure 1, generated by the NVivo software, the key words highlighted or most commented 
during the interview showing the relationships between audit, communication, ESG and risk among other rightful thoughts.

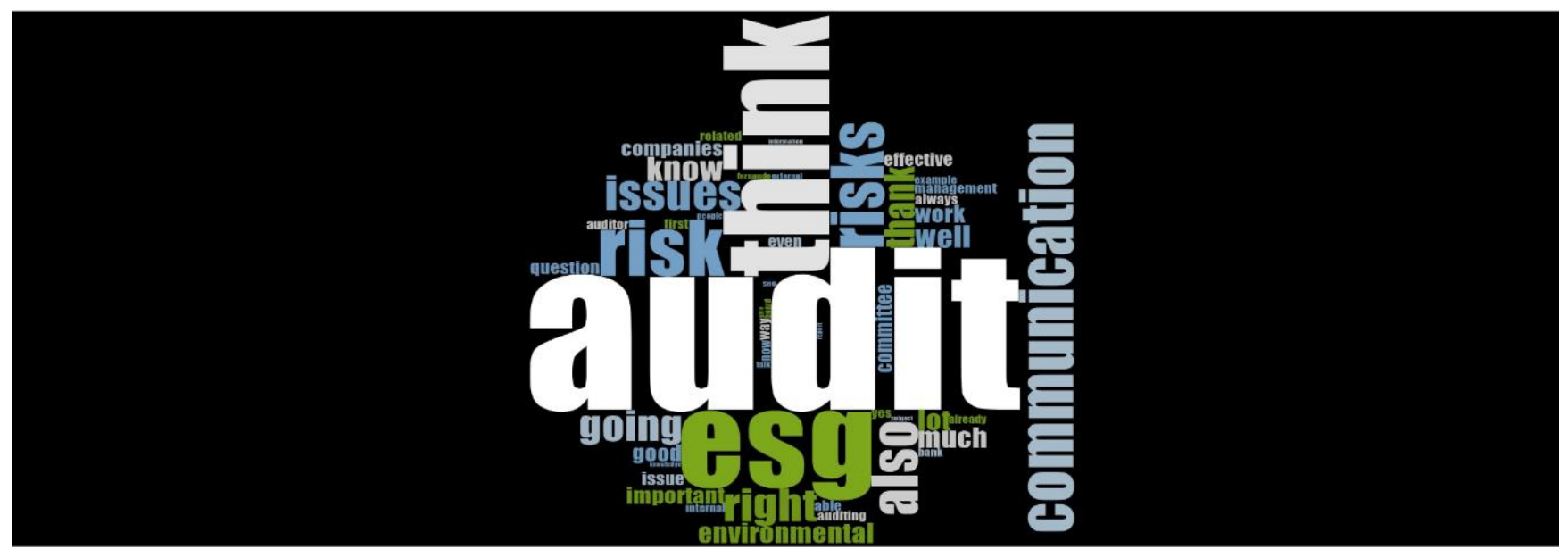

Figure 1. Cloud words on relationships between audit, communication, ESG and risk.

Additionally, we verified, through the coding generated by the NVivo software, the main themes suggested by the interviewees, grouped according to Figure 2, which we highlight here, and which will be discussed in the sequence are: Audit, Risk, Plan and Effective Communication. These suites the representation of this study according to Merriam (2002) and King (2004) on categorical analysis that manifests the following reflexivity.

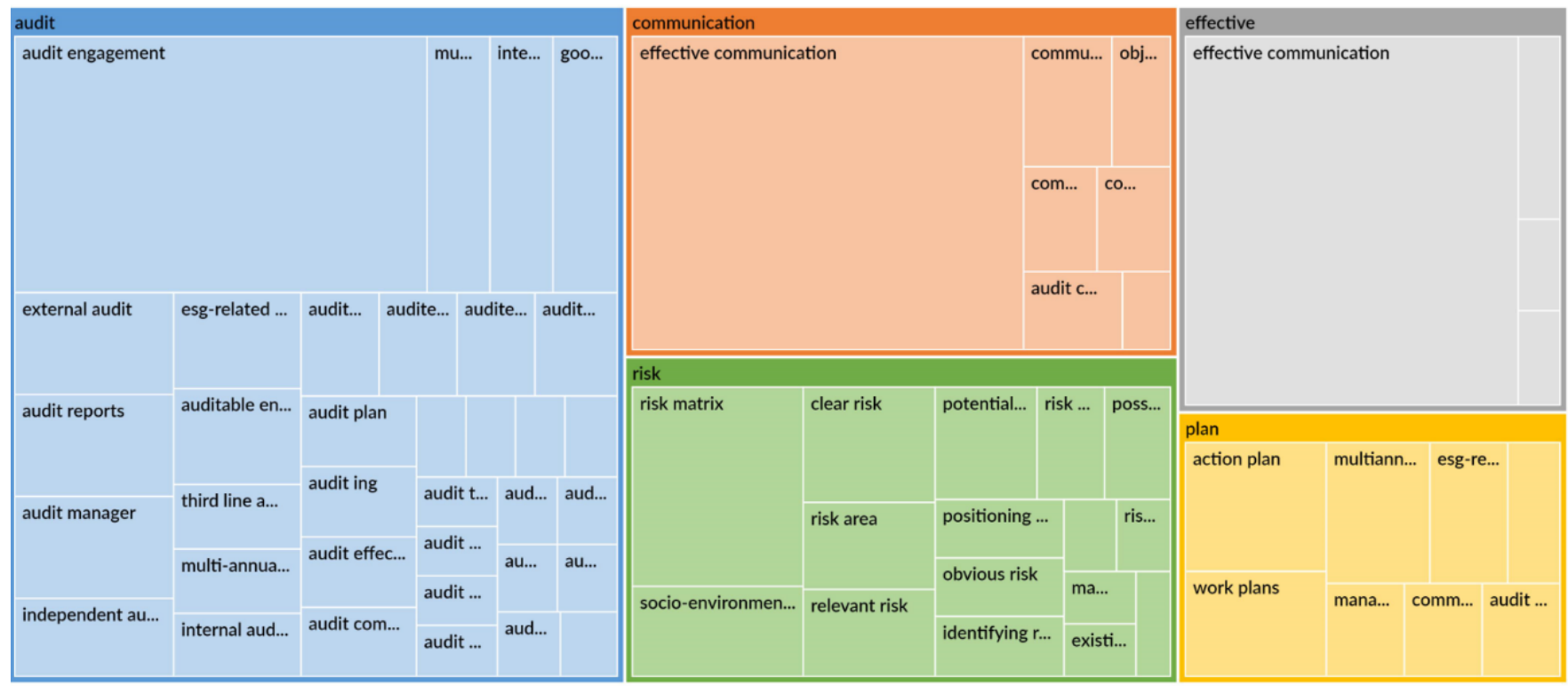

Figure 2. Main themes suggested by the interviewees. 


\subsection{The Auditing Engagement and the relantionship with ESG}

The audit engagement, whether for internal or external audit, analysed in general, comprises the actions of the audit in the field work that will result in the final communication to stakeholders. In addition, when the subject dealt with is ESG, the effective communication of audit engagements is also related to the knowledge of people and audit teams. In the interviews, the themes highlighted in Figure 3 generated by the NVivo software spotted variabilities of auditing involvement.

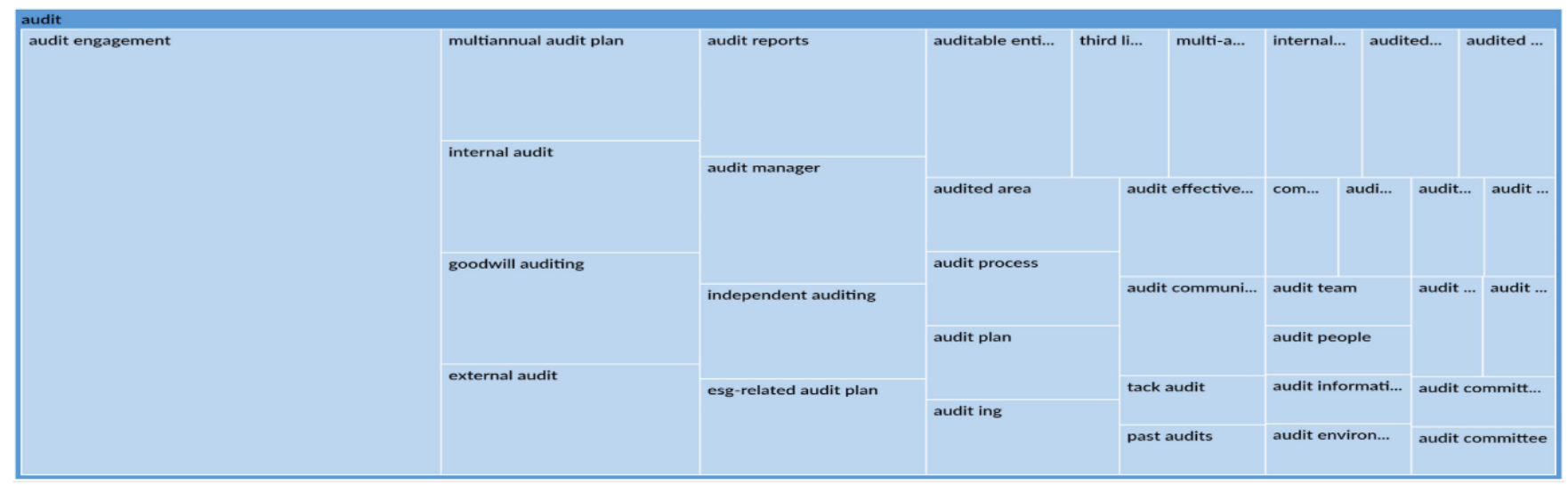

Figure 3. Variabilities of auditing involvement.

For ROR the methodological process of audit engagement should be:

In general, the auditor should have knowledge of ESG, training in business processes and audited matters, follow the action plans, evaluation, implementation and communication to senior management and the audit committee.

Another relevant subject that arose during the interviews was about ESG training for people and audit teams.

According to FFS:

Having an auditor trained in the subject, I think it is the first big step, he knows very well the topic in its essence. The second step is to know the risks of the business, focused on ESG.

RNA also follows the same reasoning:

Auditor should seek to carry out specific training with those who know a lot about the subject, has published materials that can also stress and get a lot into the detail, because, only then, knowing in depth the content is that you can apply this in all audit work.

JED thinks that:

Auditors may not be prepared to identify this risk, which is why ESG training is important. And from there, apply the normal audit program, which auditors know how to do very well.

MAG understands that:

Auditors will have a big challenge; they will need people specialized in socio-environmental risks. Initially they will hire consultancies specialized in the subject to carry out the work. 


\subsection{Audit Risk Matrix}

The risk matrix for the preparation of audit work is one of the phases of the methodology that aims to prioritize the execution of audit engagements of greater relevance. In this context, the NVivo software coded the themes of the interviews according to Figure 4.

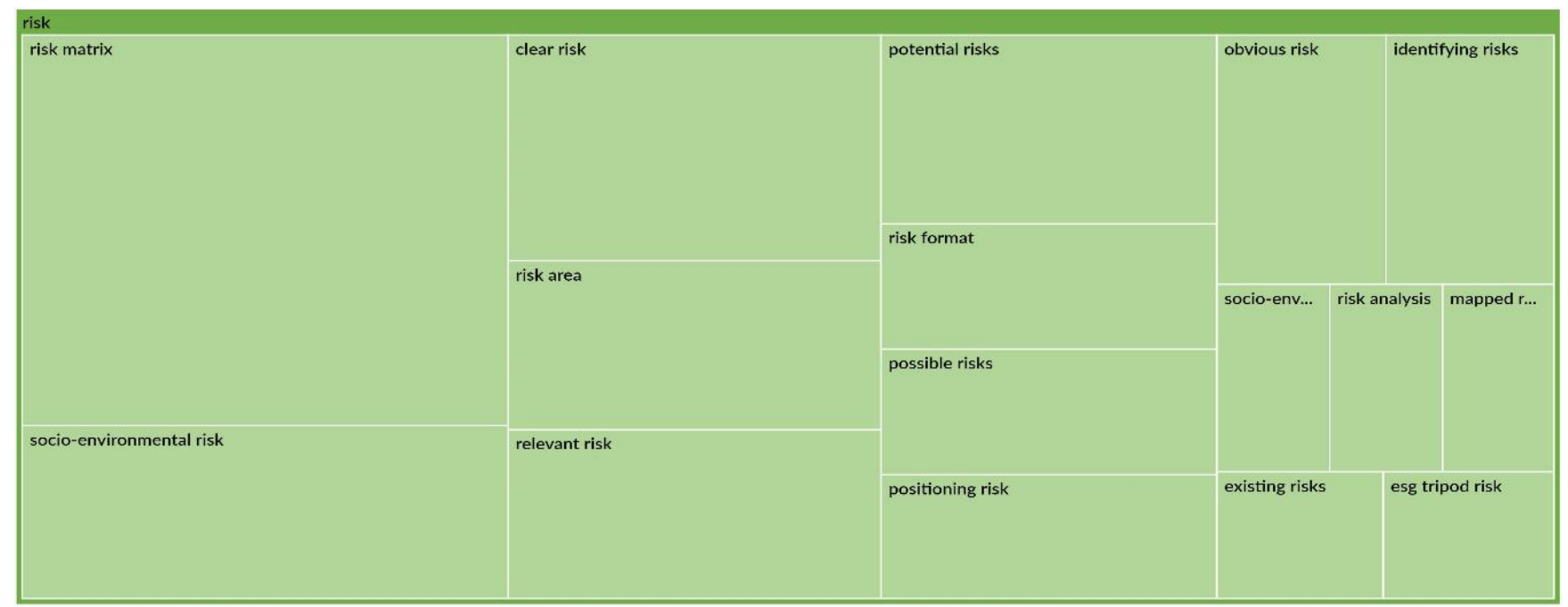

Figure 4. Risk types and matrix.

The interviewees generally expressed concerns about the issue of knowledge and the survey of ESG risks by the auditors.

According to TIY:

For these issues to be addressed strategically and consolidated in the organization, and especially in audits, a good start is to have this vision already in its risk matrix. And by the relevance that the subject is being addressed, it is very likely that the risk matrix will show a more severe graduation than previously for the ESG.

For MAG:

We need to do the exercise indoors, to map these risks, and verify that we really have any ESG risk in the company, go through the entire value chain and all auditable entities, and identify whether the risks can impact ESG issues.

According to JED, the risk matrix preparation phase is important to identify the risks of ESG:

When the audit makes the survey of the risks of the company, at this time it has to have the vision of all risks, including those related to ESG.

JES thinks that:

When we do the entire annual audit plan, we have to set up, first, a risk matrix and within this risk matrix we include an Item of ESG and evaluate if this risk is in all the pillars there within the risk matrix.

The same thought for FET:

If you do not have an effective mapping of the risks, you will hardly find any expressive conclusion. 
RNA suggests having open communication between the areas of risk and compliance and auditing:

So, it is important to know the controls and concerns that the company also has, then do all the mapping of what the company has to mitigate risks of ESG.

\subsection{Audit Planning}

The audit planning usually takes place after the result of prioritizing audit engagements, according to the risk matrix. Audit planning can be divided to have a multiannual plan and a plan for each audit engagement, to be executed by the audit team. The NVivo software brought important planning spectrum mentioned during the interviews and demonstrated in Figure 5.

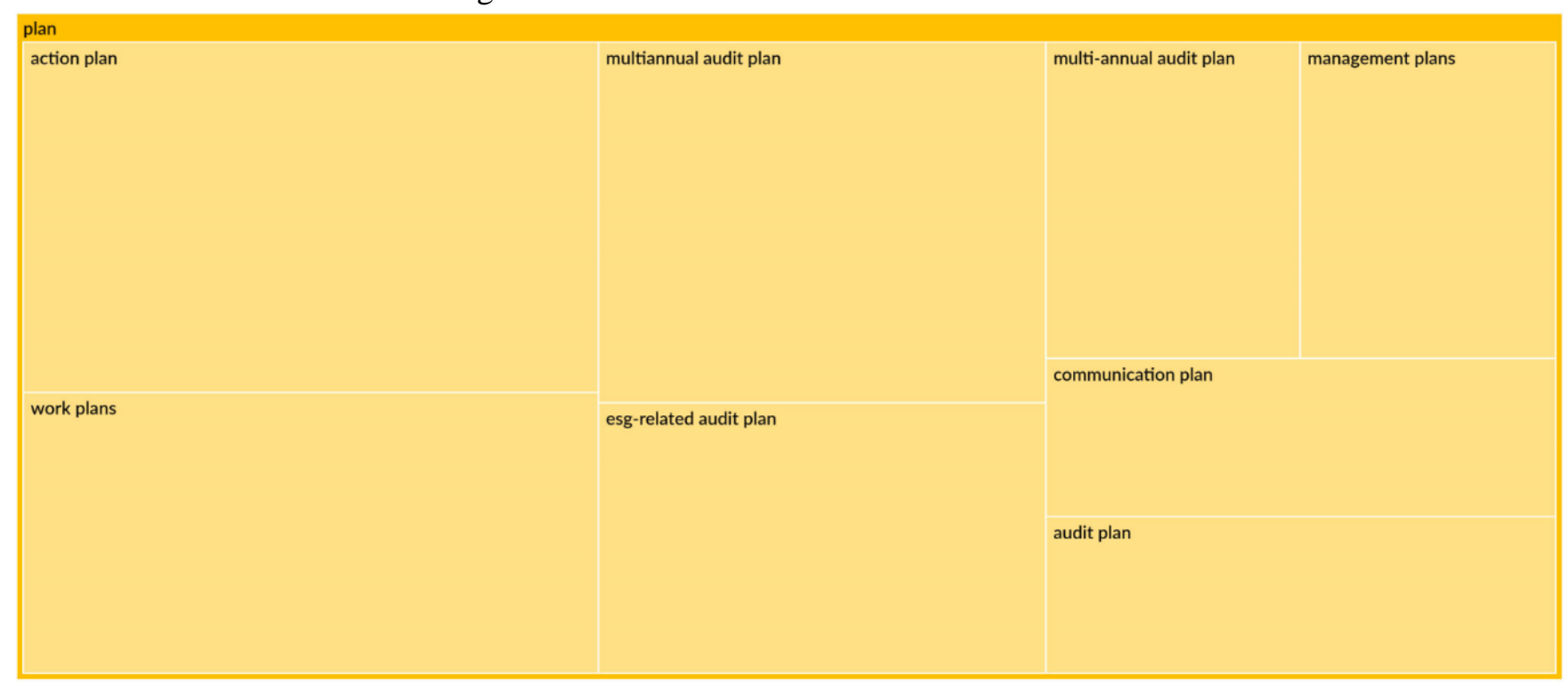

Figure 5. Planning spectrum.

For JES the result of the risk matrix is the starting point for planning ESG jobs:

Classifying the risk of ESG between high, medium or low, then we will do the audits, according to the annual plan, according to the identified risk.

Likewise, TIY, the process of communicating ESG issues can begin at this stage of audit planning.

As is recommended in best practices, the audits discuss their multiannual audit plan, at various levels of the organization, with the responsible units and with the responsible boards, committees involved, audit committee if any, and finally, with the board of directors. Here is an important channel for audits to communicate ESG issues to organizations at these various levels.

For FFS the execution of the planning of the works depends on the budget planned.

I think that the company mainly has to have a specific budget focused on ESG, clear investments, a board of directors that also looks at this topic very carefully, and that understands the risks there, which involves the company's business. 


\subsection{Effective Audit Communication}

The theme effective audit communication appeared expressively during the interviews, demonstrated in Figure 6 extracted from the NVivo software, both the aspect of means of communication itself and its effectiveness. This is because the completion of the auditor's engagement is summarized in his communication after already negotiating with the auditee.

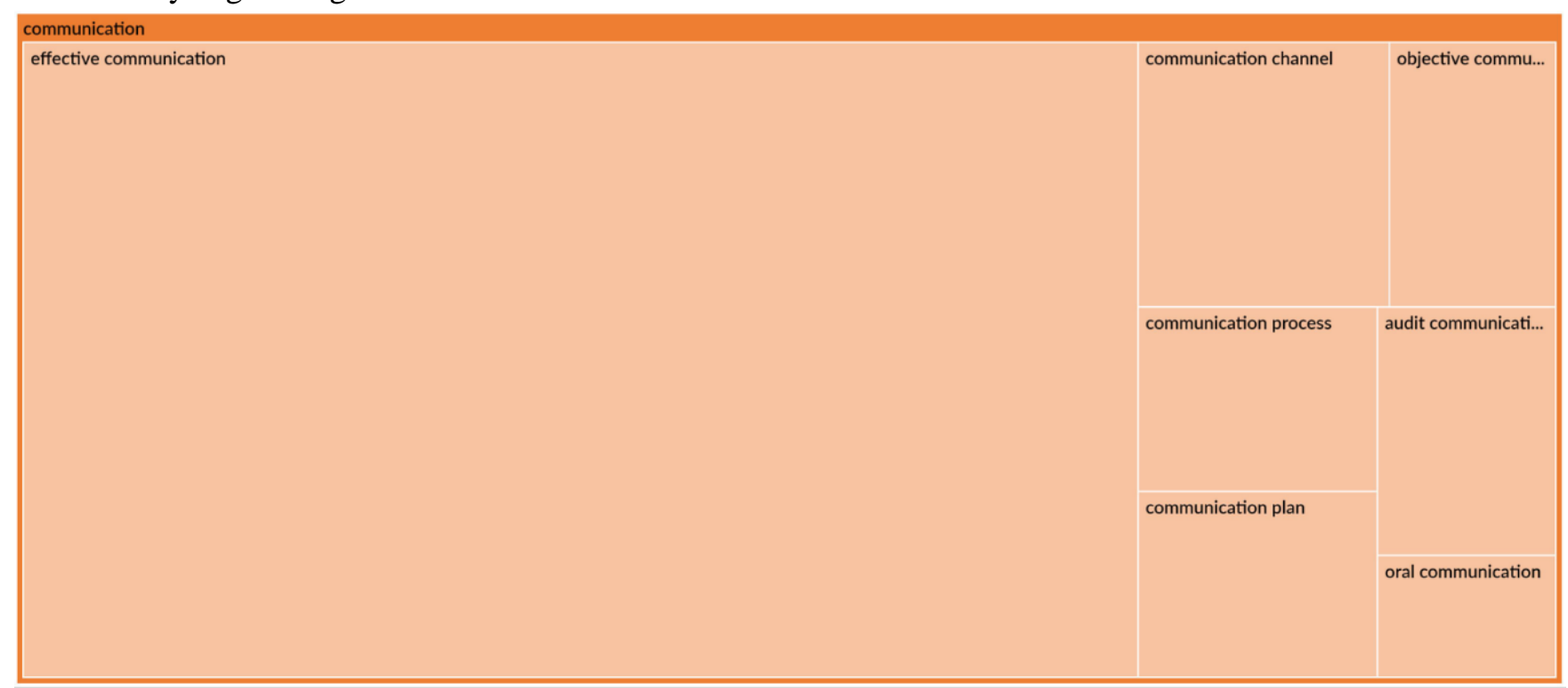

Figure 6. Effective communication and types.

The tone, the strategy, hegemonic or not Laclau and Mouffe (2001) of the communication or whether political and sociological must be harnessed so that the user of the report is able to derive from the communication the expected interpretation.

For TIY it is important that the company has a strategic vision for ESG issues, thus permeating communication at various levels of the organization:

And audits can observe whether there is a consensus or not of uniformity on the importance and approach of each ESG tripod risk. Especially if the board already has a clear, strategic vision on the treatment of ESG. So, all the reports of your results are discussed at the various levels of the organization.

For MAG:

Reporting ESG issues to the audit committee, raising awareness of company directors, and informing the board of directors is an extremely important issue.

For JED:

Eventually, if any ESG-related weaknesses are identified, you should write this in the reports and get to the right people in the company.

JES understands that:

Having independence and actually being able to report either in report or verbally is paramount. So, when we talk about effective communication, I think the primordial is independence and objectivity. 


\section{ENTREPRENEURSHIP AND SUSTAINABILITY ISSUES}

ISSN 2345-0282 (online) http://jssidoi.org/jesi/

2021 Volume 9 Number 1 (September)

http://doi.org/10.9770/jesi.2021.9.1(7)

Yet, according to PCM:

Effectively communicating what is wrong or deviating, sometimes the auditee takes it personally, maybe the communication has not been effective, or perhaps creates a barrier.

In the same line of thought FET observes:

Effective communication not only for ESG, I think is the great challenge of the auditor. I think it's more you understand, trying to find an ideal means of communication for that interlocutor, depending on what hierarchical level he is.

CAR brings innovative thinking, inserting the concept of agile auditing during the communication process:

It makes a lot more sense to me that communication is timely, just as agile auditing works. As soon as you add value, passing the information as it is identified. So, you don't have to have a formalization of a report, consolidating everything that has been identified, because in the meantime the company may be exposed to risks.

\section{Discussion}

The results of our analyses show that the ESG theme is still evolving, although there are already several measurement patterns and indicators to rule on criteria for adherence and understanding of the relationships between auditing communication and ESG risks. One of the ways to find a strength in the communication of the adoption of the ESG criteria by companies is to have an assurance by the audits. Thus responding to our research question that augmented on what is the understanding of the relationship between audit communication and ESG risks.

The Central Bank of Brazil with its agenda \#BC Sustainabilidade (2020)] also brings the highest challenge of Brazilian financial institutions in the aspects of sustainability and, being this a regulatory body, will do the supervision within its standards of best practices. Thus, the governance bodies of companies, whether financial institutions, or others that depend on financial operations, such as fundraising in the financial market, will have to charge the various areas of organizations to meet the required ESG criteria. For this they can count on the support of the work of the auditing, acting as the third line of defense, communicating independently and objectively, thus ensuring the reports to stakeholders.

\subsection{Planning as the Basis of Effective Audit Communication}

The planning of audit engagement is the starting point for achieving effective audit communication. In the internal audit function, the audit plan is usually done based on annual audit cycles, so that the auditor can test all priority business processes and their respective internal controls.

A multiannual plan requires the audit team, first, the knowledge of the business in which the company operates, and this is also valid for the ESG criteria. Knowing the business and the environment are skills that are sine qua non for the effectiveness of the auditing (Chambers, 2017). This is important because the ESG criteria can be understood differently, considering the materiality of their exposure. For example, selective garbage collection from an accounting office in the service sector may have less materiality than the disposal of hospital waste from the health sector when the environmental criteria for garbage disposal are applied.

Another subject much commented during our research was the hiring of third parties to, at first, support the audit engagements of ESG. This support by third parties could be a specific training by situating the auditor in the business and ESG context, or other than a third-party audit engagement, with the possibility of field training of the contracting company's internal audit team.

Additionally, considering the motto tone at the top, understanding what the board of directors, the audit committee and the directors of the company expect about communicating the ESG criteria to the market. It should 


\section{ENTREPRENEURSHIP AND SUSTAINABILITY ISSUES}

ISSN 2345-0282 (online) http://jssidoi.org/jesi/

2021 Volume 9 Number 1 (September)

http://doi.org/10.9770/jesi.2021.9.1(7)

also be considered that the non-adherence to such criteria can negatively impact the company's position in the market in which it operates. In other words, the loss of investors, for not being able to raise funds in the financial market, or even by the loss of customers, who will accept green products and services, which meet the ESG criteria.

For internal audits, according to The IIA (2017), the audit planning of the internal audit activity should be based on a documented risk assessment, carried out at least annually. The information provided by the senior management and the board should be considered in this process.

\subsection{Risk Analysis for Prioritizing Audit Engagements}

The stage of construction of the risk matrix and the prioritization of audit engagements is essential for the assessment of the necessary resources that the internal audit will need for the subsequent execution of the audit engagements. This step should be aligned with the vision of risks and controls that the company has.

In the audit risk matrix, the risk variable named ESG should be contemplated for each auditable entity or for each business process of the company. This variable, as well as the others, should be evaluated according to the exposure to the risks that the company has, considering the inherent risk to the company's operation and the control risk, according to the level of maturity of its internal controls, focused on the ESG criteria, thus resulting in the residual risk that can be classified as high, moderate or low risk.

However, when talking about the ESG variable, it is worth opening all the criteria adopted for each letter of the ESG, considering the scenario of where the company is inserted. For example, an agro-industrial company should consider in its variable ESG, in its letter E, aspects such as forest deforestation, burning and carbon emissions, excessive use of pesticides, pollution of water sources, etc. For each letter of the acronym ESG, a series of sub-variables can be created, with the objective of seeking assertiveness in the analysis of the risk in question. After including the ESG variable in the risk matrix and reaching the graduated residual risks of each business process, the audit will be able to prioritize its audit engagements and also quantify the resources necessary for the execution of the work, and subsequent issuance of its reports.

\subsection{Performing Audit Engagements}

Whether internal or external, the audit must be inserted in a corporate governance environment that safeguards the hierarchical independence of the auditor, such as reporting directly to the board of directors. The auditor should also have proficiency in the subject focus of the audit, so knowledge about the business to be audited Chambers (2017) and ESG is essential at this time. However, during the planning of audit engagements this was taken into account, but during execution, auditors should delve into the details of the operation of internal controls that support the company's business processes. At this stage, the training of auditors in matters related to the business and ESG criteria should have already happened, because the gaps of knowledge of such issues have already been considered in the planning phase.

When one refers to the internal auditors, according The IIA (2017) they must possess the knowledge, skills and other skills necessary to perform their individual responsibilities. The internal audit activity must collectively possess, or obtain, the knowledge, skills and other skills necessary to perform its responsibilities.

During the execution of the audit engagement, the auditor must also act with professional zeal, considering the use of specific methods to be able to complete his job effectively. This is also very essential with the ESG criteria. 


\subsection{Effective Communication}

The Figure 7, extracted from the NVivo software, provides a relational summary of the comments of the communication subject during our research. It is worth highlighting the aspect of having effective audit communication, with transparent information of the findings on ESG that were identified during audit engagements and that should be reported.

In general, an effective communication of the results of the audit should follow some essential attributes such as those mentioned in the performance standard 2420 cited in The IIA (2017), which says that communications should be accurate, objective, clear, concise, constructive, complete and timely.

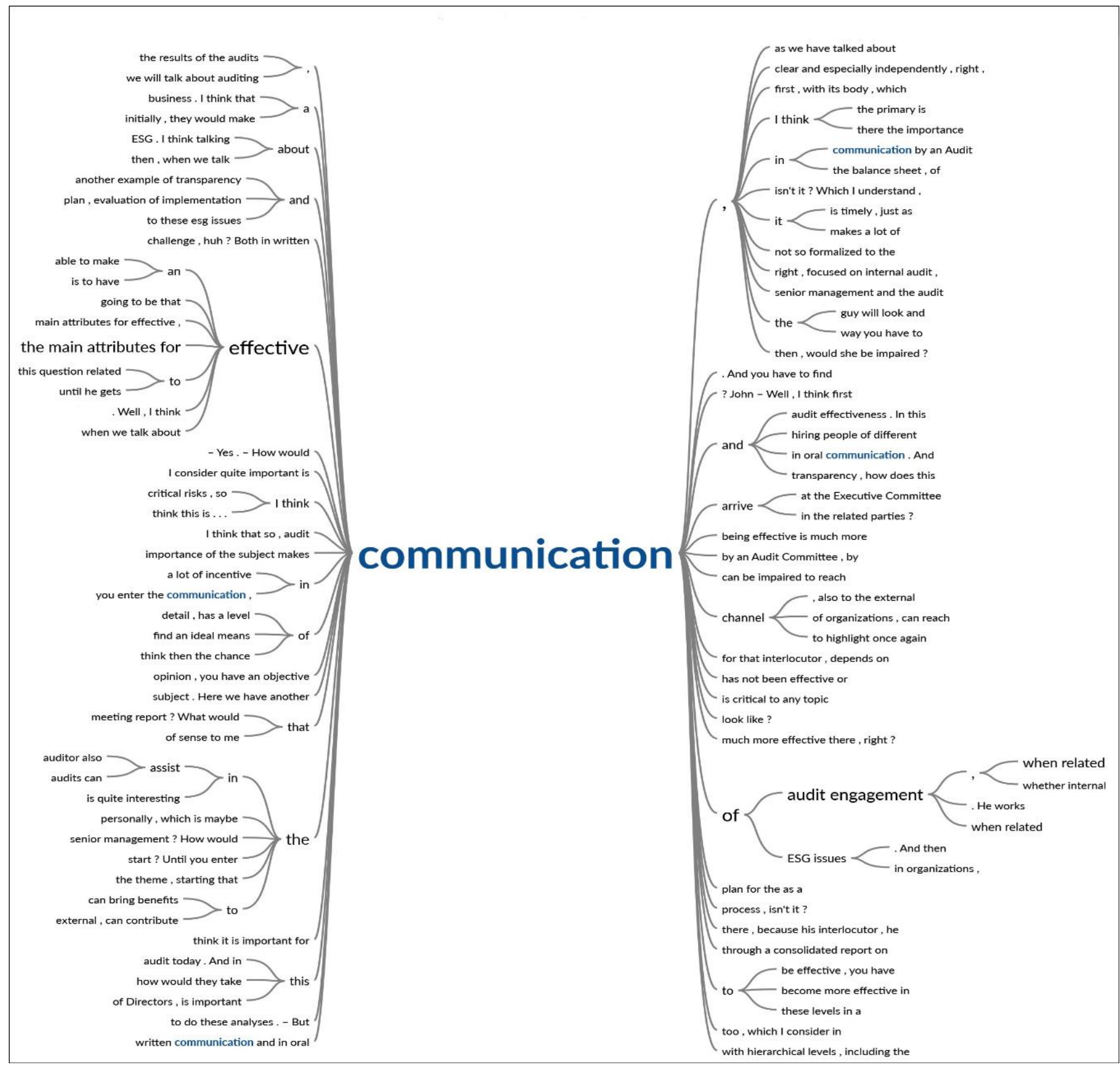

Figure 7. Relational summary between auditing communication and ESG 


\section{ENTREPRENEURSHIP AND SUSTAINABILITY ISSUES}

ISSN 2345-0282 (online) http://jssidoi.org/jesi/

2021 Volume 9 Number 1 (September)

http://doi.org/10.9770/jesi.2021.9.1(7)

In other words, when the field work is finished, the auditor has as its next step the preparation of the audit report. This follows the methodological criteria and standardized by the profession of the auditor. It is usually sought to describe the attributes of an audit report in a clear, objective way and that adds value to the internal controls and business processes of organizations.

However, when discussing the effective communication of the audit on ESG issues, the subject goes beyond the report, going through questions of technical knowledge of how to audit, metrics and standards to be followed, organizational policies adopted, and how to report in order to obtain an efficient result, especially situations that require rapid adjustments so as not to harm the company's results, whether in the short, medium or long term. This timing fits into the current and rapidly adapted environment, which we are experiencing, like the home office work, which many companies had to adapt to, due to the new coronavirus pandemic. The agile method that emerged in the area of Information Technology for software development, was disseminated to other areas of the companies, including auditing, which brings to the auditors a greater reflection on how to report the results of their work quickly. According to Tysiac (2020), audits that adopt agile methodology accelerate their deliveries.

However, the attributes of independence and objectivity were considered essential for the practice of auditing, regardless of the current worldview. Noteworthy that such attributes are sine qua non principles for the existence of the audit and, consequently, of its effective communication. This will require the auditor, a greater competence to communicate orally and adapt the objective message to the various interlocutors. For PWC (2018) auditors need communication skills, but one skill in communication is to adapt the tone. In other words, the auditors are much more likely to achieve success in facilitating change if they avoid appearing accusatory or threatening in their communications.

Overall, the hegemonic discourse surrounding the communication of audit in ESG environment seems to be that which embraces all the required standards and also draws upon the possible interpretation stakeholders would make. This is the discourse that fits the majority of stakeholders' expectation on how the auditing communication should be developed to mitigate ESG risks.

\section{Conclusions}

This research provides an understanding of the relationships between the sustainability standards adopted by organisations, the role of the auditor and the effective communication of the audit on the ESG criteria. The evolution of the ESG theme in several countries has shown concern on the part of stakeholders to obtain healthy, measurable and reliable information from companies.

Thus, to comprehend the relationship between auditing and communication on ESG issue, understanding risk analysis and the matrices, planning and rules of effective communication turns sine qua non condition. In this same vein, a well written report and communicated in a timely manner instils confidence in the auditee by procuring response, accordingly, giving remedies to weaknesses without fear or favour.

Also, our analyses revealed that audits will play a key role in demonstrating, through their methodologies, assurance to the internal users and the capital market that they are competent to carry out the work related to the ESG criteria adopted by the companies and communicate them effectively. It is also worth saying that in the academic environment it has brought to light the issue of sustainability that recommends its inclusion in auditing course, since it is a subject that will have greater importance for the training of auditors in the new future.

Yet, regarding the training of auditors on ESG, the research reveals that there is a relationship between the knowledge that the auditor must have about the company's business, the economic sector to which it is inserted and the ESG criteria, with the objective of identifying the intersections and materiality of the subject of sustainability to be considered in the planning of audit engagements.

Noteworthy that the principles of independence and objectivity of the audit are the starting point for reaching the effective communication on ESG issues. In addition, methodology wise, planning requirements should be harnessed in the audit work, the preparation of a risk analysis, based on materiality and impact matrix, with the 


\section{ENTREPRENEURSHIP AND SUSTAINABILITY ISSUES}

ISSN 2345-0282 (online) http://jssidoi.org/jesi/ 2021 Volume 9 Number 1 (September) http://doi.org/10.9770/jesi.2021.9.1(7)

appropriate variables of ESG risks, the execution of audit engagements with professional proficiency and zeal, until it arrives in effective communication to stakeholders, whether an oral or written communication, considering the technical attributes of a final audit report.

Another aspect to be considered in the process of communicating the audit engagements is the interpersonal relationship between auditors, auditee and related areas, thus providing a reliable environment for the execution and completion of work done. The communication between the audit team, directors, audit committee and board of directors and other governance bodies should be transparent, in order to maintain the alignment of the company's strategy and the vision of risks among all interlocutors.

All these findings allow us to envisage a new perspective in the audit work related to the ESG criteria, bringing the auditor as the protagonist in addition to ensuring the measurement of the sustainability indicators of companies, being an independent agent using a systematized language to bring effective communication of responses to ESG questions to stakeholders. Thus, this study contributes to reflexivity of aspects concerning the academia, practitioners and the general stakeholders thus abridging the existing understanding on the auditor and auditee relationship, communication and ESG criteria.

Finally, in our view, there can be new steps toward future studies, as the ESG theme follows the evolution of business trends. Therefore, deductive studies to identify in detail the impact of the variables of ESG risks for the various economic sectors and for companies in an individualized manner are necessary, so that it increases the level of assertiveness in the measurement of risk indicators.

\section{References}

Archambeaut, Deborah; Rose, Morgen. The ABCs of Communicating Results. Back to the Basics. Internal Auditor. 2010. https://ecommons.udayton.edu/acc_fac_pub/63/

Australian Stock Exchange. Listing Rule 4.10.17. Available online. https://www.asx.com.au/documents/ rules/gn10_operations.pdf. (Accessed on 11 April 2021).

Bătae, Oana Marina; Dragomir, Voicu Dan; Feleagăa. Liliana. Environmental. Social Governance (ESG) and financial performance of European banks. Accounting \& Management Information Systems / Contabilitate si Informatica de Gestiune. 2020, 19(3), 480-501. https://www.ceeol.com/search/article-detail?id=899304

BC\#Sustentabilidade (2020). Available online. https://www.bcb.gov.br/content/about/presentationstexts/ BCB_Agenda_BChashtag_Sustainability_Dimension_Sep2020.pdf (accessed on 24 March 2021).

Bobek, Donna D; Daugherty, Brian E.; Radtke, Robin R. Resolving Audit Engagement Challenges through Communication. Auditing. A Journal of Practice \& Theory. 2012, 31(4) https://doi.org/10.2308/ajpt-50210

Brasil. Produtos e Serviços ESG - Bolsa de Valores B3. Available online. http://www.b3.com.br/pt_br/b3/ sustentabilidade/produtos-eserviços-esg/apresentacao/. (Accessed on 1 May 2021).

Brazil Central Bank. Launch of the Sustainability Dimension of the Agenda BC\#. Brazil. 09 September, 2020. Available online. https://www.bcb.gov.br/en/pressdetail/2353/nota. (Accessed on 24 April 2021).

Castka, P.; Searcy, C.; Fischer, S. Technology-enhanced auditing in voluntary sustainability standards: The Impact of COVID-19. Sustainability. 2020, 12, 4740. https://doi.org/10.3390/su12114740

Chambers, Richard F. Trusted Advisors Key Attributes of Outstanding Internal Auditors. Internal Audit Foundation. 2017, Florida USA. https://scholar.google.com.br/scholar?q=related:PFHhNNRpOcMJ:scholar.google.com/\&scioq=Trusted+Advisors+Key+Attributes+of +Outstanding+Internal+Auditors.+Internal+Audit+\&hl=pt-BR\&as_sdt=0,5

Chambers, Richard. 10 Things Not to Say in an Internal Audit Report. Available online. https://iaonline.theiia.org/blogs/chambers/2017/Pages/10-Things-Not-to-Say-in-an-Internal-Audit-Report.aspx May 30.2017. (Accesses on 11 April 2021).

Chatterji, A.K.; Durand, R.; Levine. D.I.; Touboul. S. Do ratings of firms converge? Implications for managers. investors and strategy researchers. Strateg. Manag. J. 2016, 37, 1597-1614. https://doi.org/10.1002/smj.2407 


\section{ENTREPRENEURSHIP AND SUSTAINABILITY ISSUES}

ISSN 2345-0282 (online) http://jssidoi.org/jesi/ 2021 Volume 9 Number 1 (September) http://doi.org/10.9770/jesi.2021.9.1(7)

China (2021) China quer sistema nacional de comercio de direitos de emissão de carbono China. Available online. https://agenciabrasil.ebc.com.br/internacional/noticia/2015-11/china-quer-sistema-nacional-de-comercio-de-direitos-de-emissao-de. (Accessed on 11 April 2021).

China State-Owned Assets Supervision and Administration Commission. Directive. Available online. http://en.sasac.gov.cn/2019/11/20/c_2894.htm (Accessed on 11 April 2021).

Climate Disclosure Standards Board. The CDSB Reporting Framework; Available online. https://www.cdsb.net/ (Accessed on 11 April 2021).

Cohen, Jeffrey; Gaynor, Lisa Milici; Krishnamoorthy. Ganesh; Wright. Arnold M. Auditor Communications with the Audit Committee and the Board of Directos: Policy Recommendations and Opportunities for Future Research. Accounting Horizons. 2007, 21(2), $165-187$. https://doi.org/10.2308/acch.2007.21.2.165

Delmas, M.; Blass. V.D. Measuring Corporate Environmental Performance: The Trade-O_s of Sustainability Ratings. Bus. Strateg. Environ. 2010, 19. 245-260. https://doi.org/10.1002/bse.676

Derry, S.J. A fish called peer learning: Searching for common themes. In Cognitive Perspectives on Peer Learning; O’Donnell, A.M., King, A., Eds.; Routledge: New York, NY, USA, 1999, 197-212. https://scholar.google.com.br/scholar?hl=ptBR\&as_sdt=0\%2C5\&q=A+fish+called+peer+learning $\% 3 \mathrm{~A}+$ Searching+for+common+themes.+In+Cognitive+Perspectives+on+Peer+ Learning $\% 3 \mathrm{~B}+\mathrm{O}$ 'Donnell $\% 2 \mathrm{C}+\mathrm{A} . \mathrm{M} . \% 2 \mathrm{C}+\mathrm{King} \% 2 \mathrm{C}+\mathrm{A} . \% 2 \mathrm{C}+\mathrm{Eds} . \% 3 \mathrm{~B}+$ Routledge $\&$ btnG $=$

Eccles, Robert. G; George Serafeim, Michael P. Krzus. Market Interest in Nonfinancial Information, Journal of Applied Corporate Finance, 2011, 23(4), 113-127. https://doi.org/10.1111/j.1745-6622.2011.00357.x

Escrig-Olmedo, E.; Muñoz-Torres, M.J.; Fernandez-Izquierdo. M.A. Socially responsible investing: Sustainability indices. ESG rating and information provider agencies. Int. J. Sustain. Econ. 2010, 2, 442-461. https://doi.org/10.1504/IJSE.2010.03549

Fornelli, Cindy. Improving Audit Quality through Auditor Communication. Charting Recent Progress and Looking Ahead. The CPA Journal. 2016. https://www.proquest.com/openview/5a6df8ba1dfc256b8fc1c8ccb41ae200/1 ?pq-origsite=gscholar\&cbl=41798

Garcia, A. S.; Mendes-Da-Silva, W. \& Orsato, R. J. Sensitive industries produce better ESG performance: Evidence from emerging markets. Journal of Cleaner Production. 2017, 150(1), 135-147. https://doi.org/10.1016/j.jclepro.2017.02.180

Gill, R. Discourse analysis. In Qualitative Researching with Text, Image and Sound. A Practical Handbook; Bauer, M.W., Gaskell, G. Eds.; Sage Research Methods: London, UK, 2000, 172-190. https://books.google.com.br/books?hl=pt$\underline{\text { BR\&lr}=\& i d=\text { gnCEgt0VopkC\&oi=fnd\&pg=PP1\&dq=Discourse+analysis.+In+Qualitative+Researching+with+Text, }+ \text { Image }+ \text { and }+ \text { Soun }}$ d.+A+Practical+Handbook\%3B+Bauer,+M.W.,+Gaskell,+G.+Eds.\%3B+Sage+Research+Methods:+London, + UK, $+2000 \& 0 t s=$ rGn2O CC-xf\&sig=JikFiGts_ybK_Xsa9ji0WBzEy1I\#v=onepage \&q\&f=false

Giudice, Alfonso Del; Rigamonti, Silvia. Does Audit Improve the Quality of ESG Scores? Evidence from Corporate Misconduct. Sustainability. 2020, 12, 5670; https://doi:10.3390/su12145670

Goldhaber, Gerald M.; Krivonos, Paul D. The ICA Communication Audit: Process. Status. Critique. The Journal of Business Communication. 1977, 1. https://doi.org/10.1177/002194367701500104

Golen, Steven R.; Catanach, JR. Anthony, H; Moeckel, Cindy. The Frequency and Seriousness of Communication Barriers in the Auditor Client Relationship. Business Communication Quarterly. 1997, 60. 3. 25-37. https://doi.org/10.1177/108056999706000303

Hargie, Owen; Tourish, Dennis; Wilson, Noel. Communication Audits and the Effects of Increased Information: A Follow-up Study. The Journal of Business Communication. 2002, 39(4) https://doi.org/10.1177/002194360203900402

Sustainable Development https://doi.org/10.1007/978-3-319-63007-6Goals . Available online. https://sdgs.un.org/goals. (Accessed on 11 April 2021).

Imoniana, J. O. Ethics and auditing competence in assurance of risk of frauds: an interpretive phenomenographic analysis. Middle-East Journal of Scientific Research, 2021, 29, 1, 30-48. https://doi.org/10.5829/idosi.mejsr.2021.30.48.

Imoniana, J.O.; Imoniana, B.B.S. Auditors' career development and personal identity crisis. European Research Studies Journal. 2020.23. 565-586. https://www.ersj.eu/journal/1572

Imoniana, J.O.; Silva, W.L.; Reginato, L.; Slomski, V.; Slomski, V.G. Sustainable Technologies for the Transition of Auditing towards a Circular Economy. Sustainability. 2021, 13, 218. https://doi.org/10.3390/su13010218.

India (2021) Índia planeja se tornar uma superpotência em energia renovável até 2030 (India). Available online. https://www.ecodebate.com.br/2019/01/28/india-planeja-se-tornar-uma-superpotencia-em-energia-renovavel-ate-2030-artigo-de-jose- 


\section{ENTREPRENEURSHIP AND SUSTAINABILITY ISSUES}

ISSN 2345-0282 (online) http://jssidoi.org/jesi/ 2021 Volume 9 Number 1 (September) http://doi.org/10.9770/jesi.2021.9.1(7)

eustaquio-diniz-

alves/\#: :text=A\%20meta\%20para\%202030\%20\%C3\%A9.todos\%20os\%20aspectos\%20da\%20economia.\&text=O\%20pa\%C3\%ADs \%20pretende\%20substituir\%20770.mais\%20econ\%C3\%B4mica\%20e\%20mais\%20acess\%C3\%ADvel). (Accessed on 11 March 2021).

International Integrated Reporting Council (IIRC). Available online. https://integratedreporting.org/ news/iirc-welcomes-investor-agendafor-corporate-esg-reporting/. (Accessed on 11 April 2021).

International Standards Organization (ISO 26000). Available online. https://www.iso.org/ iso-26000-social-responsibility.html. (Accessed on 11 April 2021).

Johannesburg Stock Exchange. Listing requirements. Available online. https://www.jse.co.za/ our-business/sustainability. (Accessed on 1 May 2021).

King, N. Using templates in the thematic analyses of text. In Essential guide to qualitative methods in organizational research. Cassell, C.; Symon, G. (Ed.). Sage: London, UK, 2004, 256-270. https://scholar.google.com.br/scholar?hl=ptBR\&as_sdt=0\%2C5\&q=Using+templates+in+the+thematic+analyses+of+text.+In+Essential+guide+to+qualitative+methods+in+organ izational+research.+Cassell\%2C+C.\%3B+Symon\%2C+G.+\%28Ed.\%29.+Sage\%3A+London\&btnG=

Laclau, E.; Mouffe, C. Hegemony and socialist strategy: towards a radical democratic politics. 2nd ed.; Verso: London. UK. 2001. https://books.google.com.br/books?hl=ptBR\&lr=\&id=yblvDwAAQBAJ\&oi=fnd\&pg=PR7\&dq=40.\%09Laclau,+E. \%3B+Mouffe,+C.+Hegemony+and+socialist+strategy:+tow ards+a+radical+democratic+politics.+2nd+ed.\%3B+Verso:+London.+UK.+2001.+\&ots=cC91pIGWJ2\&sig=byuMVVSu48aj1_Tf4GV $\underline{30 M s 0 \mathrm{eUk} \# \mathrm{v}=\text { onepage } \& \mathrm{q} \& \mathrm{f}=\text { false }}$

Leal Filho, W. Handbook of Sustainability Science and Research, 2018. Springer, Switzerland.

Marks, Normam. Focusing on Internal Audit Communications. Available: https://iaonline.theiia.org/blogs/marks/2017/Pages/Focusing-oninternal-audit-communications.aspx.

Materiality principle definition. Available online. https://www.accountingtools.com/articles/2017/5/14/ the-materialityprinciple\#: :text=The\%20materiality $\% 20$ principle $\% 20$ states $\% 20$ that.statements $\% 20$ would $\% 20$ not $\% 20$ be $\% 20$ misled. (Accessed on 11 April 2021).

Merriam, S. B. Qualitative research in practice. Examples for discussion and analysis. Jossey-Bass: San Francisco, USA, 2002, 37-39. https://scholar.google.com.br/scholar?hl=ptBR\&as_sdt=0\%2C5\&q=42.\%09Merriam\%2C+S.+B.+Qualitative+research+in+practice.+Examples+for+discussion + and + analysis. + Jo ssey-Bass $\% 3 \mathrm{~A}+\mathrm{San}+$ Francisco\%2C+USA\%2C+2002\%2C+37-39.\&btnG=

Miralles-Quirós, M. M.; Miralles-Quirós, J. L. \& Gonçales, L. M. V. The value relevance of environmental, social and governance performance: The Brazilian Case. Sustainability. 2018, 10(3), 574. https://doi.org/10.3390/su10030574

Nizam. E., Ng. A.; Dewandaru. G.; Nagayev. R. \& Nkoba. M.A. The impact of social and environmental sustainability on financial performance: A global analysis of the banking sector. Journal of Multinational Financial Management. $2019,49,35-53$. https://doi.org/10.1016/j.mulfin.2019.01.002

Paris (2021) Acordo de Paris Sobre o Clima Paris. Available online. https://www.wwf.org.br/informacoes/ noticias_meio_ambiente_e_natureza/?77471/Acordo-de-Paris-completa-cinco-anos-com-licoes-aprendidas (accessed on 11 April 2021).

PWC. Agile Auditing Mindset over Matter. 2018. Available online. https://www.pwc.co.uk/ audit-assurance/assets/pdf/agile-auditing.pdf. (Accessed on 24 April 2021).

Qureshi M. A; Kirkerud, S.; Kim, T. \& Tanveer, A. Roy, D'cunha. A Collaborative Check-up. Hewlett-Packard's internal audit department looks to prevent debilitating injury to the business through open communication. Internal Auditor. April. 2013. https://go.gale.com/ps/anonymous?id=GALE\%7CA328421854\&sid=googleScholar\&v=2.1\&it=r\&linkaccess=abs\&issn=00205745\&p $=\mathrm{AONE} \& \mathrm{SW}=\mathrm{W}$

Scott, Craig R.; Shaw, Sandra Pride; Timmerman., C. Erik; Frank, Volker; Quinn, Laura. Using Communication Audits to Teach Organizational Communication to Students and Employees. Business Communication Quarterly. 1999, 62(4). 53-70. https://doi.org/10.1177/108056999906200406 


\section{ENTREPRENEURSHIP AND SUSTAINABILITY ISSUES}

ISSN 2345-0282 (online) http://jssidoi.org/jesi/ 2021 Volume 9 Number 1 (September) http://doi.org/10.9770/jesi.2021.9.1(7)

Shelby, Annete N; Reinsch, JR N, Lamar. The Communication Audit: A Framework for Teaching Management Communication. Business Communication Quarterly. 1996, 59(2), 95-108. https://doi.org/10.1177/108056999605900208

Singapore Stock Exchange. Policy Statement on Sustainability Reporting. Available online. https://www.sgx.com/regulation/sustainabilityreporting. (Accessed on 1 May 2021).

Sustainability Accounting Standards Board (SASB). Available online. https://www.sasb.org/about/ sasb-and-other-esg-frameworks/. (Accessed on 1 May 2021).

Global Reporting Initiative (GRI-G4). Available online. https://www.globalreporting.org/standards/media/1100/mapping-g4-to-thegristandards-disclosures-quick-reference.pdf (Accessed on 11 April 2021).

Szczepankiewicz, Elżbieta Izabela. Identification of Going-Concern Risks in CSR and Integrated Reports of Polish Companies from the Construction and Property Development Sector, Risks, 2021. 9(5), 1-31 https://doi.org/10.3390/risks9050085

The IIA - Institute of Internal Auditors. International. Standards for the Professional Practice of Internal Auditing (Standards). Available online. https://na.theiia.org/standards-guidance/public\%20documents/ ippf-standards-2017.pdf. (Accesses on 11 April 2021).

The impact of sustainability (environmental, social, and governance) disclosure and board diversity on firm value: The moderating role of industry sensitivity. Business Strategy and the Environment, 2019. 29(3), 1199-1214. https://doi.org/10.1002/bse.2427Miralles

Quirós, M. M.; Miralles-Quirós, J. L. \& Gonçales, L. M. V. The value relevance of environmental, social and governance performance: The Brazilian Case. Sustainability. 2018, 10(3), 574. https://doi.org/10.3390/su10030574

The Ten Principles of the UN Global Compact. Available online. https://www.unglobalcompact.org/ what-is-gc/mission/principles. (Accessed on 1 May 2021).

Tysiac, Ken. Three Lines Model for risk management gets major update. Available online. Journal of Accountancy. 20 July 2020. Available online. https://www.journalofaccountancy.com/news/2020/jul/ 3-lines-of-defense-model-for-risk-management-gets-majorupdate.html. (Accessed on 24 April 2021).

United Nations Development Programme. Human Development Report. Available Online. http://hdr.undp.org/en/content/ Accessed 25 April 2021.

Vodovoz, Inna; Robinson, Christine; Sullivan, Kristen. \#DeloitteESGnow Enhancing Trust in ESG Disclosures. Deloitte \& Touche LLP. Heads up. 2020, 27(20) https://dart.deloitte.com/USDART/home/publications/deloitte/heads-up/2020/deloitteesgnow-enhancing-trustin-esg

World Economic Forum (2020). Measuring Stakeholder Capitalism Towards Common Metrics and Consistent Reporting of Sustainable Value Creation. Available online. https://www.weforum.org/ reports/measuring-stakeholder-capitalism-towards-common-metricsand-consistent-reporting-of-sustainable-value-creation. (Accessed on March April 2021). 


\section{ENTREPRENEURSHIP AND SUSTAINABILITY ISSUES}

ISSN 2345-0282 (online) http://jssidoi.org/jesi/ 2021 Volume 9 Number 1 (September) http://doi.org/10.9770/jesi.2021.9.1(7)

Washington LOPES da SILVA is a Post Doctorate candidate, Department of Accounting, University of Sao Paulo. Interests: Auditing, AIS.

(iD

https://orcid.org/0000-0003-0657-9626

Joshua Onome IMONIANA is a Professor of Auditing, University of Sao Paulo. Research interests: Auditing, AIS, Forensic Accounting.

iD

http://orcid.org/0000-0002-6535-6863

Make your research more visible, join the Twitter account of ENTREPRENEURSHIP AND SUSTAINABILITY ISSUES: @Entrepr69728810

Copyright (C) 2021 by author(s) and VsI Entrepreneurship and Sustainability Center

This work is licensed under the Creative Commons Attribution International License (CC BY).

http://creativecommons.org/licenses/by/4.0/

(c) (i) Open Access 